\title{
Water Information Programs in Kansas
}

Mission of the

U.S. Geological Survey

The U.S. Geological Survey (USGS), an agency within the U.S. Department of the Interior, serves the Nation by providing reliable scientific information to describe and understand the Earth; minimize loss of life and property from natural disasters; manage water, biological, energy, and mineral resources; and enhance and protect our quality of life.

\section{Water Programs in Kansas}

The USGS has collected hydrologic information in Kansas for more than 100 years. This information consists of streamflow and gage-height data; reservoir content; water-quality and water-quantity data; suspended-sediment data; and groundwater levels. Hydrologic studies are conducted on statewide, regional, and local levels. The USGS in Kansas works cooperatively with 31 Federal, State, and local agencies, such as the Kansas Water Office, the U.S. Army Corps of Engineers, and the City of Wichita.

\section{Recent Activities of the}

\section{U.S. Geological Survey in Kansas}

\section{National Programs}

- Research into occurrence and movement of pesticides; antibiotics; and algal toxins, taste, and odor compounds in the environment

- Streamflow data visualization

- Application of hydrologic modeling to USGS National Water-Quality Assessments

\section{Statewide Programs}

- Streamflow monitoring at more than 180 locations for flood forecasting, reservoir operations, and many other uses

- Monitoring of real-time water-quality conditions at 34 locations

- Compilation of Kansas municipal and irrigation water-use data

- Assessment of sedimentation in Kansas reservoirs

\section{Programs in Congressional District 1}

- Determination of water-quality conditions in Cheney Reservoir and watershed

\section{Programs in Congressional District 2}

- Monitoring of hydrologic conditions at Fort Riley

- Baseline sediment studies in Perry Lake watershed.

- Determination of water-quality conditions on the Kickapoo Reservation

- Clinton Lake sediment quality

- Ozark aquifer water availability and water quality

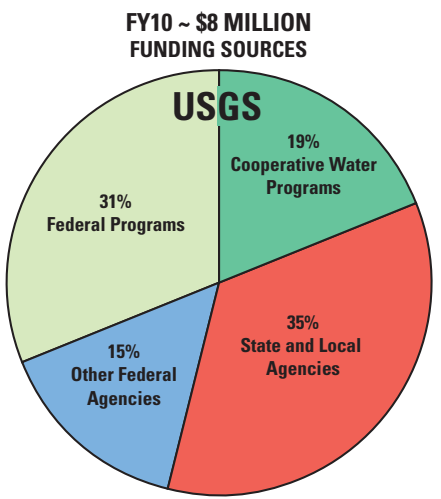

- John Redmond Reservoir sediment study

- Neosho River streambank stabilization study

\section{Programs in Congressional District 3}

- Determination of biology and stormwater quality in Johnson County streams

\section{Programs in Congressional District 4}

- Determination of water-quality and quantity effects of Equus Beds aquifer recharge project

- Flood warning and inundation mapping on Cowskin Creek, Wichita

\section{USGS STREAMFLOW, LAKE-ELEVATION, AND WATER-QUALITY GAGES}

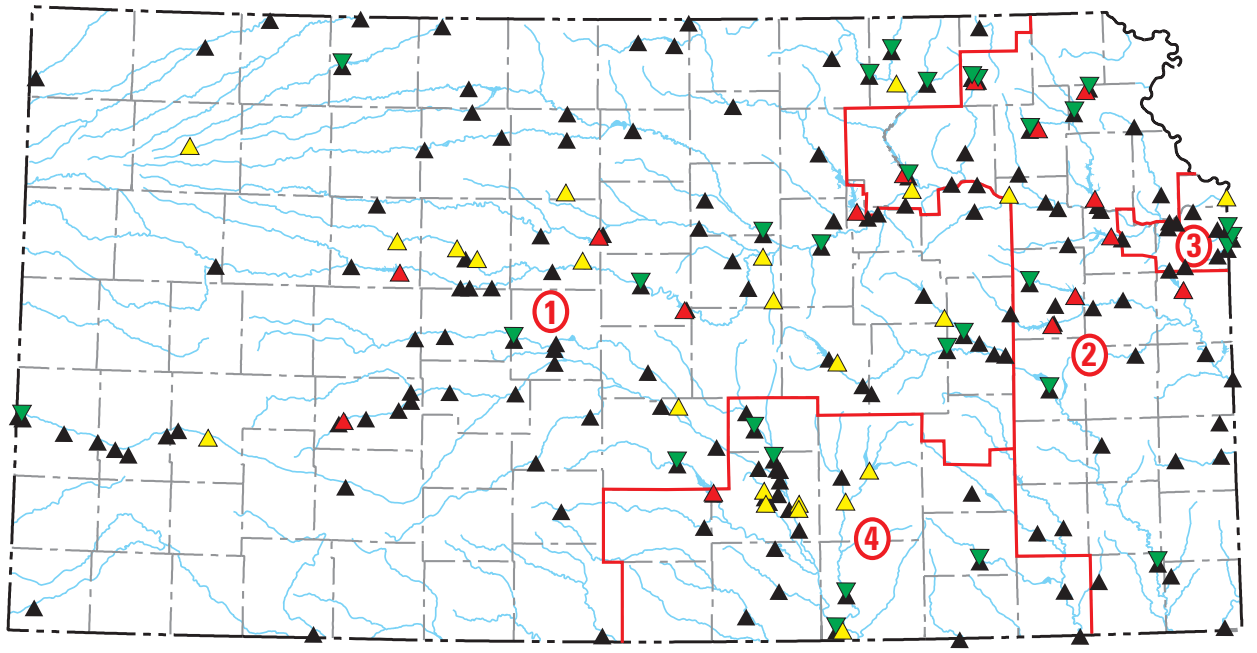

\ Streamflow gage

$\triangle$ High-flow stream gage
$\Delta$ Lake-elevation gage

$\nabla$ Water-quality gage - Boundary of Congressional District 


\section{USGS Streamflow Information}

Continuous real-time streamflow information is a vital Kansas asset that can safeguard lives and property and ensures adequate water resources for a healthy State economy. The USGS operates more than 180 streamflow-monitoring stations in Kansas. Most of these stations are cooperatively funded in partnerships with local, tribal, State, and other Federal agencies. The USGS real-time water-monitoring network provides long-term, accurate, and unbiased information that meets the needs of customers. This was particularly evident during the 2000-2006 drought and the 2007 floods.

http://waterdata.usgs.gov/ks/nwis/rt

\section{Uses of Continuous Real-Time Streamflow Information}

- State and local water-management and supply agencies - to plan, monitor, regulate, and adjust water withdrawals

- National Weather Service River Forecast Centers-to determine flood stages for various streams and to help forecast when and where streams will crest during floods

REAL-TIME STREAMFLOW CONDITIONS

Thursday, March 10, 2010 10:30ET

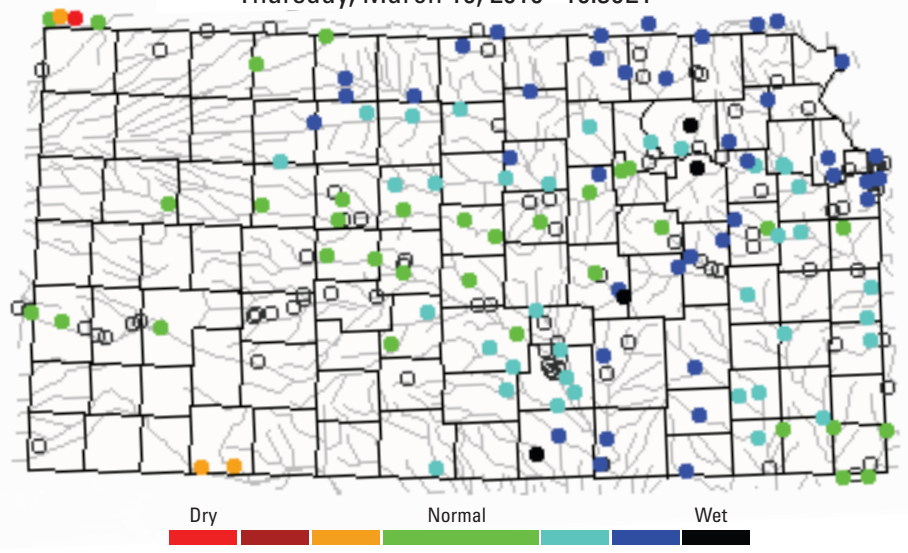

- U.S. Army Corps of Engineers-to most efficiently schedule reservoir releases

- Kansas Department of Transportation-to safely and efficiently design bridges, highways, and culverts that will convey sufficient streamflow so that roadways and bridges remain above water during flooding and escape structural damage
- Federal Emergency Management Agency-to delineate flood-prone areas, develop flood-insurance rates, and address emergencyresponse needs before, during, and after flooding

- Fishermen, swimmers, and boaters-to monitor water conditions for safe, optimum recreational use

\section{City of Wichita Water Supply}

The water supply for the City of Wichita, south-central Kansas, currently (2010) comes from the Equus Beds aquifer and Cheney Reservoir. Because these sources are not expected to meet projected city water needs into the 21 st century, artificial recharge of the Equus Beds aquifer using excess streamflows from the Little Arkansas River is being investigated by Wichita with assistance from the USGS (beginning in 1995); this is being implemented as one alternative to meet future water supply. An additional potential benefit of artificial recharge includes preventing degradation of the water quality of the aquifer by saltwater plumes from the Arkansas River to the southwest and the Burrton oil field to the northwest. The Equus Beds Aquifer Storage and Recovery (ASR) Project Phase I began in 2006.

\section{The USGS role in activities with the City of Wichita has been to determine:}

- Water-quality changes because of ASR

- Changes in Equus Beds aquifer storage

- Streamflow available to use for ASR

\section{Key findings:}

- Results of more than 6,000 samples indicate that the effects of artificial recharge on the water quality of the aquifer were minimal during the demonstration project from 1995 to 2000 with chloride, atrazine, and arsenic being of greatest concern

- Water storage in the Equus Beds aquifer has recovered more than half of lost storage volume since October 1992 largely because of reduced aquifer pumpage by Wichita and increased reliance on Cheney Reservoir for City of Wichita water supply

- An average of 174 days per year (1995-2008) had sufficient streamflow to meet permit requirements for recharging

http://ks.water.usgs.gov/Kansas/studies/equus/

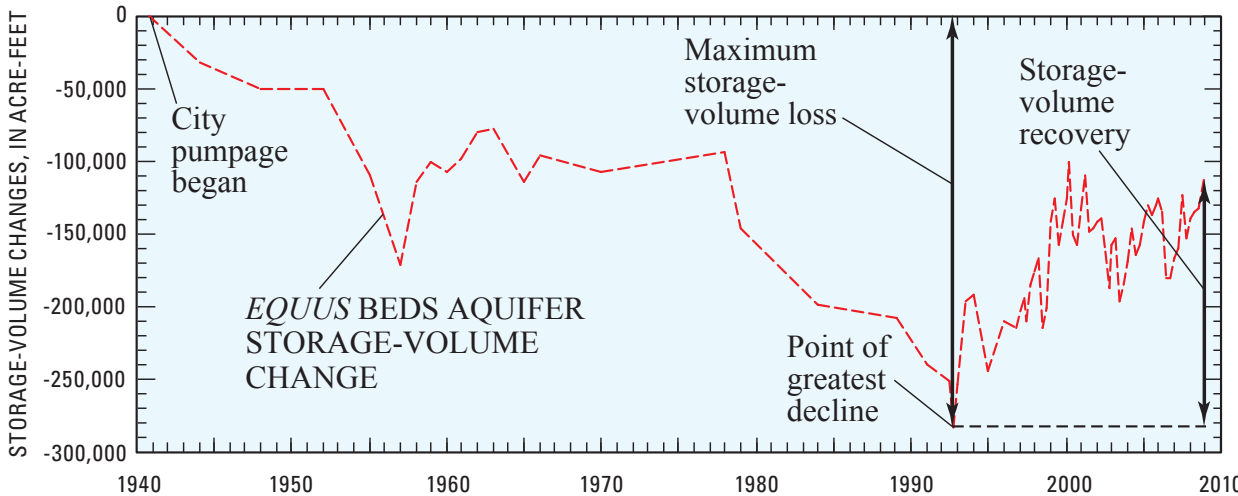

